\title{
Governança judicial como solução efetiva à oralidade no processo civil brasileiro: jurisdição sustentável
}

\author{
Judicial governance as an effective solution to orality in Brazilian civil process: sustainable \\ jurisdiction
}

La gobernanza judicial como solución efectiva a la oralidad en el proceso civil brasileño: jurisdicción sostenible

Recebido: 20/08/2021 | Revisado: 25/08/2021 | Aceito: 01/09/2021 | Publicado: 04/09/2021

\author{
Magno Federici Gomes \\ ORCID: https://orcid.org/0000-0002-4711-5310 \\ Escola Superior Dom Helder Câmara, Brasil \\ E-mail: magnofederici@gmail.com \\ Izabela Lemos de Castro Pereira \\ ORCID: https://orcid.org/0000-0002-8189-1305 \\ Pontifícia Universidade Católica de Minas Gerais, Brasil \\ E-mail: izabelalemos40@gmail.com
}

\begin{abstract}
Resumo
A litigância oral plena não é prevista no Brasil, mas é adotada em determinados atos. Entretanto, muitas das vezes esse instituto é aplicado de forma inadequada, ou sequer é aplicado, já que a lei estabelece, geralmente, uma faculdade quanto a sua utilização. Por esse motivo, torna-se indispensável um debate a fim de que se critique esse uso pelos sujeitos do processo. Para tanto, foi utilizado o método jurídico-teórico e raciocínio dedutivo, com técnica de pesquisa bibliográfica. Ao final, conclui-se que a governança judicial pode ser um meio eficaz no que tange à efetivação da oralidade e, consequentemente, a efetividade da jurisdição sustentável.
\end{abstract}

Palavras-chave: Oralidade; Uso inadequado; Celeridade procedimental; Efetividade processual; Governança Judicial.

\begin{abstract}
Full oral litigation is not foreseen in Brazil, but is adopted in certain acts. However, many times this institute is applied unevenly, or is not even applied, since the law generally establishes a faculty as to its use. For this reason, a debate is indispensable in order to criticize this use by the subjects of the process. For this, the legal-theoretical method and deductive reasoning were used, with bibliographic research technique. In the end, it is concluded that judicial governance can be an effective means, not with regard to the effectiveness of orality and, consequently, the effectiveness of jurisdiction.
\end{abstract}

Keywords: Orality; Inappropriate use; Procedural speed; Procedural effectiveness; Judicial Governance.

\section{Resumen}

La litigación oral no está prevista explícitamente en Brasil, pero suele ser utilizada en diversos actos procesales. Sin embargo, muy a menudo este instituto se aplica de manera incorrecta, o no se utiliza, ya que la ley establece la facultad para su empleo. Así que un debate científico es fundamental para criticar su utilización por los sujetos procesales. Por lo tanto, se ha utilizado el método jurídico-teórico y el razonamiento deductivo con técnica de investigación bibliográfica. Se ha concluido que la gobernanza judicial puede ser una medida para el empleo de la oralidad y, en consecuencia, la efectividad de la jurisdicción sostenible.

Palabras clave: Oralidad; Uso inapropiado; Velocidad de procedimiento; Eficacia procesal; Gobernanza judicial.

\section{Introdução}

É notório o fato de que o Brasil conta hoje com uma justiça morosa e muitas vezes inefetiva. Isso pode se dar em razão de diversos pontos, mas em especial à aplicação inadequada de institutos processuais já previstos pelo ordenamento jurídico, inclusive mediante o advento do Código de Processo Civil de 2015 (CPC/15). O CPC/15 trouxe em seu texto uma evidente preocupação legislativa em tornar o sistema judicial mais célere de forma a proporcionar decisões mais adequadas e justas aos casos concretos. 
Embora não tenha trazido muitas novidades quanto a aplicação da oralidade no processo civil, ao ser comparado com o Código de Processo Civil de 1973 (CPC/73), não deixou de lado esse instituto que goza de muita importância no cenário atual. Isso se dá em razão de sua instituição trazer uma fluidez dentro do processo, tornando seu curso mais econômico e eficaz, quando aplicado de maneira correta. Entretanto, é necessário questionar: o uso do princípio da oralidade está sendo empregado adequadamente na litigância civil brasileira?

A investigação pretende aplicar princípios básicos de governança participativa judicial para solucionar as críticas que a oralidade na litigância vem sofrendo, em especial a possibilidade de configuração de corrupção judicial lato sensu.

A pesquisa se justifica na medida em que a comunidade acadêmica anseia pela aplicação adequada dos institutos disponibilizados pela lei processual e, por isso, é necessário um constante debate de métodos e meios que agregariam qualidade a essa utilização diuturna, buscando sempre a celeridade e efetividade da jurisdição sustentável.

No primeiro capítulo, serão evidenciados os aspectos conceituais, tanto no CPC/15 quanto no CPC/173, da oralidade e seus principais impactos no processo. No segundo, serão apresentadas algumas estratégias de litigância oral no direito processual civil brasileiro. No terceiro capítulo, será analisada, criticamente, a utilização da oralidade no sistema judiciário brasileiro, dentro da litigância civil. Por último, foi apresentada uma solução passível de agregar na aplicação da oralidade, em especial no que tange ao comportamento das partes e do próprio magistrado.

\section{Metodologia}

Para responder o questionamento supramencionado, foram utilizados na realização deste artigo o método jurídicoteórico e raciocínio dedutivo, com técnica de pesquisa bibliográfica. O marco teórico da pesquisa é o texto de Ruiz e Rossaneis (2013).

Assim, a pesquisa científica utilizou a doutrina e legislação. O raciocínio dedutivo emprega argumentos gerais para chegar às considerações finais. Essa técnica costuma ser utilizada por pesquisadores que empregam o raciocínio lógico, já que haverá uma relação lógica entre as premissas e as conclusões, segundo Mezzaroba e Monteiro (2009, p. 65).

\section{Aspectos Conceituais no Código De Processo Civil de 2015 e no Código De Processo Civil de 1973}

O CPC/15 surge, sem sombra de dúvida, em um cenário conturbado, onde prevalece um estado de morosidade no Poder Judiciário brasileiro, embora o que prevalece é o direito à razoável duração do processo, direito fundamental amparado no art. $5^{\circ}$, inciso LXXVIII, da Constituição da República Federativa do Brasil (CRFB/88). Essa realidade acontece pela carga intensa de demandas, causada diretamente, mas não unicamente, pelo pensamento popular de que a jurisdição é o único meio efetivo para se resolver conflitos de interesses, sejam individuais ou coletivos. Portanto, na família romano germânica do Direito tem-se a ideia que é sempre necessário a palavra final de um terceiro, no caso o juiz, para a melhor solução possível à questão litigiosa, ou seja, para dizer o direito. Também é possível pensar que a morosidade se dá, em partes, pelo atuação, nem sempre efetiva e célere, dos servidores públicos e dos órgãos pertencentes ao Poder Judiciário, embora não é possível dispensar o fato de que "O número de funcionários, juízes, auxiliares, é escasso, sendo humanamente impossível prestar eficiente trabalho diante da numerosa quantidade de processos. Quanto aos juízes, devido à escassez de profissionais hábeis a assumir o cargo, passam a se responsabilizar por mais de uma Comarca ou Vara com sobrecarga de trabalho" (Maranguape \& Maranguape \& Vasconcelos, 2020, s.p.).

É através do processo que se torna possível a solução da lide, sendo possível às partes obterem aquilo que é de seu direito. Entretanto, é justamente nesse ponto que deve ser questionada a questão da morosidade, já que "o processo é o meio pelo qual o Poder judiciário exerce a jurisdição" (Maranguape, Maranguape \& Vasconcelos, 2020, s.p.). A morosidade é, 
portanto, empecilho ao exercício da jurisdição de forma efetiva e justa, e uma solução adequada e viável para uma jurisdição mais célere é reformas e adequações quanto as etapas do processo.

Em razão dessa situação, foi estruturado o CPC/15 justamente com a preocupação de, ao menos, atenuar a morosidade judiciária, ao trazer princípios e medidas que amparariam o processo civil de forma geral, visando torná-lo mais célere e consequente mais efetivo, uma vez que não há de se falar em efetividade em um processo que demora anos para promover às partes aquilo que elas têm direito, através do provimento final de mérito, inviabilizando muitas vezes o acesso à justiça. A morosidade causa insegurança às partes e, por isso, conforme afirmam Gomes e Ferreira:

[...] para fins de sustentabilidade, a morosidade do Poder Judiciário, na entrega da tutela jurisdicional, necessita ser combatida, pois o jurisdicionado precisa de uma resposta jurídica para seu conflito, em tempo hábil a produzir seus efeitos, de modo que o bem da vida em disputa ainda esteja posto à disposição e não tenha se deteriorado em razão do tempo [...]. Cabe destacar, ainda que seja por meio da conciliação ou do provimento final de mérito, que o desfecho processual precisa ser realizado em tempo hábil a proteger ou entregar o bem da vida posto em disputa, sob pena de não estarem sendo cumpridos os preceitos constitucionais que regulam a matéria (Gomes \& Ferreira, 2017, p. 102).

Como forma de mitigar os efeitos da morosidade, tem-se o princípio da oralidade, já previsto pelo CPC/73, mas reafirmado pelo $\mathrm{CPC} / 15$, já que o mesmo, conforme já dito anteriormente no presente artigo, teve como meta primordial o alcance da celeridade procedimental e da efetividade processual.

A oralidade, em regra, trata-se de um meio de se realizar atos processuais, através da modalidade verbal, mas, conforme afirma Gouvêa (2017, p. 78-79), pode ser vista também: "como princípio, é norma que informa outras regras e subprincípios, como a identidade fisica do juiz, a imediação, a concentração dos atos e a irrecorribilidade imediata das decisões interlocutórias". Ademais, ainda segundo a autora, é necessário, para a correta aplicação da oralidade, não apenas a definição de que certos atos devem ser necessariamente efetivados de forma oral, mas é preciso pensá-la sempre visando alcançar celeridade e uma tutela efetiva.

O princípio da oralidade, trata-se, portanto, da definição de um meio de fluidez dentro das demandas, por meio da consecução de atos processuais na forma oral. Nos primeiros períodos da humanidades, pode-se afirmar, com toda certeza, que o procedimento era puramente oral, em razão da inviabilidade da escrita. Com o passar do tempo, a oralidade veio perdendo força no cenário mundial. Conforme afirma Chiovenda, acerca dos benefícios da oralidade: "a experiência deduzida da história permite concluir sem detença, que o processo oral é, com ampla vantagem, melhor e mais conforme à natureza e às exigências da vida moderna, porque exatamente sem comprometer, antes assegurando melhor a excelência intrínseca da decisão, proporciona-a com mais economia, simplicidade e presteza" (Chiovenda, 1965, p. 46).

Embora no Brasil seja notório o fato de que o processo é predominante escrito, desde a vigência do CPC/73, o CPC/15 institui momentos dentro processo em que há de se prevalecer a oralidade, em especial na produção de provas. Dessa forma, não se pode afirmar a prevalência do procedimento oral no processo brasileiro, mas também não se pode afastá-lo de suas fases.

Cabe salientar que o princípio da oralidade se desdobra em subprincípios, de indispensável entendimento, quais sejam: da documentação, da concentração, da irrecorribilidade das interlocutórias, da identidade física do juiz e da imediação.

A documentação traduz-se na exigência de que algumas alegações ou provas, feitas a priori de forma oral, sejam devidamente documentadas, ou seja, transcritas em papel. Isso está evidenciado no art. 367 do CPC/15, in verbis, embora já venha sendo admitida gravações, em imagem e som, de audiência, sendo desnecessário portanto a documentação escrita, conforme o $\S 5^{\circ}$ aduz: 
Art. 367 do CPC/15. O servidor lavrará, sob ditado do juiz, termo que conterá, em resumo, o ocorrido na audiência, bem como, por extenso, os despachos, as decisões e a sentença, se proferida no ato. $\S 1^{\circ}$ Quando o termo não for registrado em meio eletrônico, o juiz rubricar-lhe-á as folhas, que serão encadernadas em volume próprio. $\$$ $2^{\circ}$ Subscreverão o termo o juiz, os advogados, o membro do Ministério Público e o escrivão ou chefe de secretaria, dispensadas as partes, exceto quando houver ato de disposição para cuja prática os advogados não tenham poderes. $\S 3^{\circ} \mathrm{O}$ escrivão ou chefe de secretaria trasladará para os autos cópia autêntica do termo de audiência. $\$$ $4^{\circ}$ Tratando-se de autos eletrônicos, observar-se-á o disposto neste Código, em legislação específica e nas normas internas dos tribunais. $\S 5^{\circ}$ A audiência poderá ser integralmente gravada em imagem e em áudio, em meio digital ou analógico, desde que assegure o rápido acesso das partes e dos órgãos julgadores, observada a legislação específica. $\S 6^{\circ}$ A gravação a que se refere o $\$ 5^{\circ}$ também pode ser realizada diretamente por qualquer das partes, independentemente de autorização judicial (Brasil, 2015).

O subprincípio da concentração surge para definir que a audiência oral deverá ser una e indivisível, em regra, para que as provas orais sejam produzidas todas em um só momento, o que viabiliza a efetividade do procedimento (art. 365 do CPC/15). Sabe-se que no processo civil brasileiro, esse subprincípio não vigora de forma absoluta. Por sua vez, o subprincípio da irrecorribilidade das decisões interlocutórias decorre diretamente do subprincípio da concentração, “evitando a pulverização dos atos processuais, bem como a interrupção contínua da relação jurídica processual, atendendo à celeridade e à duração razoável do processo" (Bueno, 2018, s.p.).

O subprincípio da identidade física do juiz trata-se da exigibilidade do juiz manter contato pessoal com as partes, durante todos os momentos predominantemente orais do processo, em especial na produção de provas. Sobre esse contato direto, Peyrano indica ser uma grande vantagem, mas o juiz não deverá “Por fin, descontamos que un mejor rendimiento de la práctica de la prueba, supone un juez activo que preside a la audiencia respectiva. Pero sin asumir un protagonismo absoluto.

Así, acontece que, por ejemplo, suelen ser más rendidores los interrogatorios efectuados por las partes que los materializados por el magistrado"1 (Peyrano, 2008, p. 161).

Já a imediatidade abrange diretamente a identidade física do juiz, garantindo que o juiz prolator da sentença (entrega efetiva do direito às partes) deve ser aquele que participou ativamente da produção de prova oral. Inclusive, quanto a este subprincípio, o CPC/73 possuía dispositivo muito interessante, qual seja, o art. 132, que definia que o juiz que julgaria a lide seria o mesmo que participou da audiência, ressalvados as hipóteses de impossibilidade fática para tanto, razão pelo qual o sucessor poderia requer a reprodução das provas produzidas em audiência. Isso evidencia a preocupação com a presença do juiz nos atos processuais orais.

Conclui-se, portanto, que "Mündilichkeit sein die Unmittelbarkeit der Wahrnehmung des Processstoffs durch der erkennenden Richter. Sie sagt, dass nur das unmittelbar von RichterWahrgenommene Urtheilsgrundlage ist”2 (Wach, 1879, p. 1).

O CPC/73, além do dispositivo supramencionado, possuía outros que evidenciavam a existência da oralidade processual. Um deles era o art. 454, que instituía as alegações orais como fase posterior a instrução, que também se encontra no CPC/15 (art. 364 do CPC/2015), onde os advogados de ambas as partes tinham o direito de falar perante o juiz, in verbis: “Art. 454. Finda a instrução, o juiz dará a palavra ao advogado do autor e ao do réu, bem como ao órgão do Ministério Público, sucessivamente, pelo prazo de 20 (vinte) minutos para cada um, prorrogável por 10 (dez), a critério do juiz" (Brasil, 1973).

\footnotetext{
1 Tradução livre: “assumir um protagonismo absoluto. Assim, acontece que, por exemplo, tendem a ser mais rentáveis os interrogatórios realizados pelas partes do que se materializados pelo magistrado" (Peyrano, 2008, p. 161).

2 Tradução livre: "a oralidade deve ser vista como uma possibilidade de apreensão imediata do material processual por parte do juiz. Ela determina que apenas aquilo que o julgador apreende de forma imediata pode ser considerada como fundamento de sua decisão" (Wach, 1879, p. 1).
} 
Outro dispositivo de notória importância foi o art. 446, inciso II, do CPC/73 que obrigava o juiz a colher provas, direta e pessoalmente, além de dirigir os trabalhos em audiência, assim como o art. 336 do CPC/73, que fixa como regra a prova oral:

Art. 446 do CPC/73. Compete ao juiz em especial: I - dirigir os trabalhos da audiência; II - proceder direta e pessoalmente à colheita das provas; III - exortar os advogados e o órgão do Ministério Público a que discutam a causa com elevação e urbanidade.

Parágrafo único. Enquanto depuserem as partes, o perito, os assistentes técnicos e as testemunhas, os advogados não podem intervir ou apartear, sem licença do juiz (Brasil, 1973), e

Art. 336. Salvo disposição especial em contrário, as provas devem ser produzidas em audiência (Brasil, 1973).

A título de curiosidade, o princípio da oralidade no processo alemão traz a oportunidade de ser aplicado em processos de pequena complexidade, como um todo, e na fase de audiências preparatórias, onde nesse último caso o juiz poderá escolher a predominância oral ou escrita (Gouvêa, 2017, p. 82). Essa regra não foi reproduzida no Brasil, mas por trazer benefícios ao processo, nada impede que tal técnica seja adotada no Brasil, após uma eventual discussão e alteração legislativa.

Cabe destacar que, entre a vigência do CPC/73 e a instituição do CPC/15, foi estabelecido no Brasil, por meio da Lei dos Juizados especiais (Lei 9.099/1995), a necessidade de se atender à oralidade nos processos que a lei rege. Isso está diretamente ligado a finalidade primordial da lei, qual seja, a celeridade e economia processual. Dessa forma, o procedimento regido pela lei pode ser considerado primordialmente oral, salvo as ressalvas conferidas por lei, onde o ato deve ser escrito, em razão de suas peculiaridades e exigências. Além disso, a lei ainda define a concentração dos atos instrutórios, através do art. 33, que apresenta a necessidade dos atos processuais serem reunidos em um mesmo momento, sempre quando for possível.

Ademais, existe o Estatuto da Ordem dos Advogados do Brasil, Lei 8.906/90, que em seu art. $7^{\circ}$ arrola uma série de direitos dos advogados, entre eles o de livre acesso aos Juízos, o de poder se manifestar diretamente aos magistrados em suas salas e gabinetes, inclusive sumariamente, de reclamar verbalmente perante qualquer órgão judicial, bem como junto aos Poderes Executivo e Legislativo.

$\mathrm{O}$ CPC/15 trouxe a oralidade de forma mitigada, não tendo um grande papel no processo como tinha durante a vigência no CPC/73. Conforme afirma Theodoro Júnior:

A identidade física do juiz, que era restrita no Código anterior, nem sequer foi conservada pelo Código atual. Quanto ao julgamento da causa em audiência, o Código o adota como regra do procedimento comum, mas prevê casos em que, por economia processual, o julgamento se faz antecipadamente, sem necessidade sequer da audiência de instrução e julgamento (art. 355). Quanto à irrecorribilidade das decisões interlocutórias, a orientação do Código foi totalmente contrária ao princípio da oralidade pura, pois admite o agravo de grande número de decisões proferidas ao longo do curso do processo (art. 1.015), muito embora sem efeito suspensivo (Theodoro Junior, 2005, s.p.).

Dessa forma, percebe-se que o CPC/15 poderia ter reproduzido alguns dispositivos do CPC/73, sem prejuízo de ineficácia, já que os dispositivos do Código anterior eram pertinentes e importantes à aplicação da oralidade no processo civil.

Gouvêa afirma que o fato do CPC/15 atual afirmar a cooperação entre os sujeitos como norma fundamental do processo caracteriza a necessidade de contato direito entre as partes. Isso porque a oralidade viabiliza essa cooperação, já que proporciona uma discussão. Um meio mais concreto, graças ao CPC/55, para viabilizar este contato é através dos métodos de resolução consensual de conflitos, seja através da conciliação ou da mediação (Gouvêa, 2017, p. 88).

Nessa fase, é adotado o diálogo oral como meio de solucionar o conflito existente entre as partes, já que as mesmas podem expor seu ponto de vista e o que almejam e assim entrar em um acordo que não favorece apenas uma parte, mas sim ambas. Através da conciliação ou mediação, tem-se uma solução do conflito que consequentemente evita que a demanda seja ajuizada perante Poder Judiciário, proporcionando às partes uma tutela jurisdicional mais célere e efetiva. 
Conforme conclui Gouvêa, "o CPC de 2015 conferiu a ela outra roupagem e, conjuntamente à cooperação, uma importância ainda maior na busca por um processo justo - entendido como aquele capaz de prestar uma tutela adequada, efetiva e segura às partes, com economia e celeridade processual" (Gouvêa, 2017, p. 90).

\section{Estratégias de Litigância Oral Civil}

Passa-se, então, a análise das estratégias de litigância oral no Direito Processual Civil brasileiro.

\subsection{Queima de etapas mortas no procedimento civil - intervenção direta dos advogados nas secretarias dos Juízos}

É notório que no procedimento civil sob os ditames do novo CPC/15, há consideráveis etapas que, de certo modo, atrasam o processo e afeta diretamente à duração razoável do processo. Entretanto, algumas delas podem ser chamadas de “etapas mortas”, uma vez que são totalmente dispensáveis para o alcance do resultado efetivo do processo, sendo portando meras etapas dispostas na lei sem qualquer finalidade na prática, e por isso poderiam ser facilmente dispensadas ou modificadas.

É o que se pode perceber em diligencias processuais que poderiam ser inteiramente evitadas, se fossem realizadas através da intervenção direta dos advogados nas secretarias dos Juízos. É indiscutível que na maioria das vezes, a oralidade utilizadas por meio do contato dos advogados frente aos juízes pode causar impactos mais positivos, no que tange ao tempo gasto no trâmite do processo. Ao conversar diretamente com o juiz, este pode se sentir convencido o suficiente e no mesmo momento proferir o despacho que provavelmente demoraria muito mais tempo para ser proferido. Dessa forma, a possibilidade das partes, ao invés de peticionar no processo mediante todas as diligências cabível, apresentar oralmente seus pedidos e requerimento perante o juiz, pode acarretar em um processo mais célere e consequentemente efetivo.

As etapas mortas podem ser consideradas também como aquelas que demandam, na prática, tempo superior para serem resolvidos pelo Poder Judiciário, sem trazer efetividade ao processo e sem cooperar com a sua razoável duração. Theodoro Júnior muito bem explicita esse significado por meio do seguinte trecho:

Que adianta fixar a lei processual um prazo de três ou cinco dias para determinado ato da parte, se, na prática a secretaria do juízo gastará um mês ou dois (e até mais) para promover a respectiva publicação no diário oficial? Que adianta a lei prever o prazo de noventa dias para encerramento do feito de rito sumário se a audiência só vem a ser designada para seis meses após o aforamento da causa, e se interposto o recurso de apelação, só nos atos burocráticos que antecedem a distribuição ao relator serão consumidos vários meses ou até anos? O retardamento dos processos, impende reconhecer, quase nunca decorre das diligências e prazos determinados pela lei, mas, em regra, é o resultado justamente do desrespeito ao sistema legal pelos agentes da Justiça. [...] $O$ que retarda intoleravelmente a solução dos processos são as etapas mortas, isto é, o tempo consumido pelos agentes do Judiciário para resolver a praticar os atos que lhes competem. O processo demora é pela inércia e não pela exigência legal de longas diligências (Theodoro Junior, 2005, s.p.).

Através dessa exemplificação, é cabível salientar que a não fixação de prazos obrigatórios em detrimento de determinados atos do Poder Judiciário é capaz de tornar os prazos impostos às partes inúteis, afastando-se assim da finalidade primordial da jurisdição, que é dar as partes o que elas possuem de direito, em tempo hábil e efetivo, uma vez que, caso seja alcançado o resultado final do processo anos após sua propositura, pode não ser possível mais atingir a finalidade buscada no momento da propositura. $\mathrm{O}$ processo assim se torna inútil às partes.

Ademais, outro argumento que é possível salientar, no que tange a fixação de prazos para atos do Poder Judiciário, é que, conforme afirma Lopes Jr, "as pessoas têm direito de saber, de antemão e com precisão, qual o tempo máximo que poderá durar um processo concreto[...]. É inerente às regras do jogo [...] é uma questão de reconhecimento de uma dimensão democrática da qual não podemos abrir mão" (Lopes Jr., 2004, p 113). Dessa forma, a duração razoável do processo abrange, 
pelos princípios democráticos que o direito brasileiro segue, o direito daquele que pleiteia determinado direito em juízo, de saber quando haverá uma resposta definitiva sobre o assunto, inclusive a fase satisfativa.

É até mesmo irônico fixar o prazo para interposição do recurso de apelação como sendo de 15 dias úteis, sendo que na prática processual é realmente comum o julgamento da apelação em prazo superior a 1 ano. Por esse motivo, nada mais efetivo do que a fixação de prazos para atos emanados do próprio Poder Judiciário, e que estes sejam respeitados e seja a ele impostas penalidades em caso de descumprimento. Formaria-se, assim, um prazo legal de duração razoável de um processo cível, através da queima de etapas mortas, e consequentemente uma celeridade e efetividade maior.

\subsection{Audiências especiais de organização e saneamento}

Conforme determina o $\mathrm{CPC} / 15$, no que tange ao trâmite do procedimento comum de conhecimento, em caso de não ocorrer a extinção do processo sem resolução de mérito ou o julgamento antecipado do mérito, seja parcial ou total, o juiz deverá proferir decisão de saneamento e de organização do processo. Trata-se, portanto, de uma providência imposta pelo juiz, com a finalidade de resguardar o processo de eventuais irregularidades ou nulidades que poderia prejudicar outras fases.

Cabe salientar o que Talamini afirmar como finalidade da fase saneadora: "Assim, o saneamento destina-se a propiciar eficiência à atuação jurisdicional - e consequentemente economia processual (duração razoável do processo). Mas também se presta a assegurar previsibilidade (segurança jurídica) e a tornar mais qualificado o debate entre as partes e o juiz (contraditório), ampliando-se as chances de uma solução justa e eficaz" (Talamini, 2016, s.p.).

Cabe salientar que a decisão de saneamento deve, conforme indica o art. 357 do CPC/15:

Art. 357 do CPC/15. I - resolver as questões processuais pendentes, se houver; II - delimitar as questões de fato sobre as quais recairá a atividade probatória, especificando os meios de prova admitidos; III - definir a distribuição do ônus da prova, observado o art. 373; IV - delimitar as questões de direito relevantes para a decisão do mérito; $V$ designar, se necessário, audiência de instrução e julgamento (Brasil, 2015).

O próprio $\S 3^{\circ}$ do artigo supramencionado determina a possibilidade de audiência, em razão da complexidade da matéria, "para que o saneamento seja feito em cooperação com as partes, oportunidade em que o juiz, se for o caso, convidará as partes a integrar ou esclarecer suas alegações" (Brasil, 2015).

Trata-se de regra que acarretará diversos benefícios às partes, sendo portanto uma estratégia de litigância oral civil que merece destaque. Isso porque, a presença física das partes em momento que tem como finalidade a organização do processo, pode favorecer no sentido de promover um entendimento mais amplo do juiz quanto a causa em si. Sem sombra de dúvidas, a oralidade através de audiência traz a possibilidade de compreensão mais abrangente e consequentemente, de uma decisão mais coerente e efetiva às partes. São justamente estes os benefícios da oralidade, em especial nessa fase processual.

Além disso, a instituição de audiência saneadora acarretará, necessariamente, uma cooperação entre as partes, que irão inclusive debater questões pontuais para fins de organização, prestar informações e esclarecimento que influenciam diretamente na decisão final proferida após a fase instrutória, e inclusive evitar momentos desnecessários nesta última fase. É uma medida que se impõe, visto que a cooperação entre as partes acarreta na devida dinâmica processual, a fim de que todo o trâmite se desenvolva necessariamente de forma preordenada e efetiva. Mais uma vez, as condutas cooperadas afetam diretamente na decisão do juiz que, a proferirá mais coerentemente.

Na prática, não é muito comum a audiência de saneamento, pelo fato de ser o próprio juiz que determina se aquela demanda trata-se de complexa quanto a matéria de fato ou de direito e por isso é necessário a audiência antes do despacho saneador. Nesse caso a imposição da audiência de saneamento em todas as demandas, inclusive as de menor complexidade, poderia acarretar em uma etapa desnecessária. Dessa forma, a medida que se impõe seria a preparação adequada dos 
magistrados no que tange a definição de demandas com alta complexidade de fato ou de direito. Inclusive, o próprio Conselho Nacional de Justiça (CNJ), poderia estabelecer direcionamentos nesse sentido, para que seja possível a audiência de saneamento em mais demandas que, embora sejam complexas, são julgadas por magistrados como não complexas.

\subsection{Livre convencimento dos Juízes e Magistrados dos Tribunais}

Sabe-se que a função jurisdicional é de dizer o direito e aplicá-lo ao caso concreto, na forma da lei, de forma justa e efetiva.

Para alcançar uma solução efetiva à lide, é necessário a produção de elementos para convicção do juiz. Por isso a oralidade, de forma geral, traduz-se em uma estratégica processual de grande valia no que tange o convencimento do juiz, uma vez que através dela, é possível que o juiz sinta as alegações das partes assim como de suas testemunhas, consequentemente avaliando as provas produzidas de forma mais coerente. Há, nesse caso, uma participação ativa do juiz na demanda.

\subsubsection{Nos gabinetes dos Juízes}

Conforme já mencionado no presente artigo, a oralidade pode causar diversos impactos positivos no que tange à processos mais eficientes e mais céleres, já que o Brasil vem passando por uma ascensão de demandas judiciais e consequentemente uma morosidade na solução das mesmas.

O principio da cooperação, como norma fundamental do processo civil, deve ser visto como uma forma de alcançar o devido acesso à justiça, uma vez que esse acesso pressupõe não apenas o ingresso perante o Poder Judiciário, mas também uma tutela efetiva.

Inclusive, cabe salientar os dizeres de Souza Netto (2016, p. 417): “a natureza principiológica da cooperação obriga os sujeitos processuais a pautarem as respectivas condutas, seja na iniciativa, seja no desenvolvimento do processo, em deveres de lealdade, eticidade e colaboração para o alcance de um resultado decisório que seja obra em coautoria".

Em linha tênue, está a oralidade, já que através dessa é possível que o princípio da cooperação atinja suas finalidades. A oralidade poderá levar um debate entre todos os sujeitos processuais, já que será possível que as partes sintam umas as outras, assim como o juiz sinta as partes, conforme já foi abordado no presente tópico. Por essa razão, a oralidade pode proporcionar uma discussão que levará á solução mais coerente conforme o caso concreto.

Não há dúvidas que a aplicação da oralidade pode se dar através de diversas etapas processuais, em especial no que tange á argumentação oral feita por advogados nos gabinetes dos magistrados.

É notório que o peticionamento escrito nos autos, por mais simples que sejam as diligências, é mais comum, até mesmo pelo fato de que nem sempre despachar com o magistrado é tarefa fácil, já que nem sempre estão disponíveis para uma conversa oral. Ocorre que, pelos motivos já expostos, a oralidade nos debates, mesmo que em pequenas diligências, pode impactar diretamente na decisão do juiz, de forma positiva, já que permite que este fique próximo o suficiente da questão. Por isso, as visitas dos advogados aos gabinetes deveriam ser amplamente facilitadas, ao invés de permanecer a realidade árdua no tocando ao contato direto e pessoal com o magistrado que preside a causa em que o advogado atua.

Pelos motivos acima expostos, deve-se defender a ideia da implementação da oralidade no cotidiano forense de forma mais incisiva, ao contrário de se manter sempre apego ao peticionado escrito nos autos do processo. É preciso, portanto, afastar a tradição que já vem a muitos anos fazendo parte do Poder Judiciário e, consequentemente, impactando na celeridade processual. 


\subsubsection{Nas audiências de instrução para colheita da prova}

É notório que a coleta de provas em audiências de instrução pode influenciar substancialmente na decisão, de forma que a mesma seja mais coerente de acordo com todas as provas produzidas. Isso se dá também em razão da oralidade, uma vez que em audiências, onde todas as partes estão fisicamente presentes, é possível maiores debates e um convencimento mais adequado do magistrado.

É necessário, entretanto, conforme afirma Baptista (2008, p. 142), entender que a presença da oralidade deve ser considerada tão somente quando há de fato, oportunidade de contraditório, uma vez que na prática é reconhecida em audiências pelo mero fato da presença física, mesmo quando as partes sequer são ouvidas.

Além disso, cabe destacar o quão importante é a figura física do juiz, conforme preleciona o subprincípio da identidade física do juiz, para que este mantenha um contato pessoal com as partes em momentos de produção de provas. Além disso, neste ponto, o subprincípio da imediatidade também merece destaque, visto que é através dele que é determinado a necessidade do mesmo magistrado que manteve contato pessoal com a instrução processual, ser o que prolatará sentença, pondo fim ao litígio.

Entretanto, infelizmente, os magistrados não possuem uma noção da oralidade como um meio que torna possível a celeridade processual e a efetividade das decisões. Conforme afirma Baptista, os magistrados geralmente possuem uma visão crítica e negativa sobre a instituição da oralidade na fase de instrução, inclusive entendem a oralidade como:

[...] um meio de prova a ser produzido na fase de instrução, isto é, em audiência. Todavia, um meio de prova que atrapalha o curso do processo, por ser ineficaz, por dificultar a "distribuição da justiça" e, finalmente, por impedir que se realiza um bom trabalho (...) O fato preponderante na desvalorização da prova oral no processo civil diz respeito, portanto, à descrença dos juízes nos depoimentos prestados. Isso se dá porque, na concepção jurídica, a verdade não é revelada pelas partes, é desvendada pelo juiz. A verdade jurídica está acima das partes. Logo, as pessoas não podem contribuir para sua descoberta. É o próprio sistema inquisitorial - cujas raízes se fazem presentes em nossos procedimentos - desqualificar e desconfiar do discurso dos tutelados (Baptista, 2008, p. 138140).

De toda forma, embora os magistrados possuem críticas severas sobre a produção de prova em audiência de instrução, não há dúvidas que essa produção proporciona uma verdadeira participação das partes que podem influenciar diretamente no convencimento do juiz, que através da audiência obtém contato físico com as provas que instruirão sua decisão final.

\subsubsection{Nos Tribunais e nas sustentações orais}

Merece também destaque no presente capítulo a importância das sustentações orais no julgamento de recursos perante os Tribunais. Isso porque, embora o procedimento recursal nos Tribunais seja predominantemente escrito, no momento da argumentação pelo qual se funda a sentença, é necessário que se dá de forma oral.

Os motivos que validam o argumento acima exposto é que, obviamente, nem sempre é possível expor de forma totalmente compreensiva o que a parte pleiteia, assim como os fundamentos utilizados por ela e os motivos pelos quais seus requerimentos merecem provimento. De fato, o leitor poderá ter maiores dificuldades de compreender e se convencer, enquanto o redator poderá cometer alguns erros da escritas e não se fazer transparecer assim como deveria.

Além disso, as sustentações orais nos Tribunais tendem a serem curtas, o que acaba por chamar mais atenção dos ouvintes ali presentes, pelo mero fato de não se tratar de sustentações longas, repetitivas e sem qualquer objetividade, que acabam por desprender-se da atenção dos julgadores ou mesmo levar uma confusão desnecessário na exposição perante o magistrado.

As sustentações são feitas pelosa advogados das partes, e para que se tenha a devida efetividade, sem influenciar nessa oportunidade que de fato é necessário no trâmite recursal, é preciso um domínio total do caso pelo advogado, já que é muito 
comum advogados serem constituídos e designados para o momento sem sequer ter feito uma leitura completa dos autos. Além disso, o conhecimento prévio de todo o processo é necessário para que seja possível a exposição de uma visão ampla dos fatos no momento da sustentação oral. Isso porque, obviamente, através da exposição dos fatos é que o magistrado ali presente se convencerá acerca da aplicação ou não do direito ali afirmado pela parte. Por último, é necessário uma boa oratório, que faz com que o advogado seja melhor compreendido.

Isso tudo porque de nada adianta a oportunidade da manifestação oral em sede recursal, se não for feita de forma que, efetivamente, o desembargador ali presente possa compreender as questões de fato determinantes para seu convencimento e a prolação da decisão final.

Pelos motivos acima expostos, pode-se afirmar que a oralidade presente nos Tribunais maximizam as chances das partes, uma vez que é através dela que é possível um maior convencimento dos desembargadores julgadores, já que, como já reiterado diversas vezes no presente trabalho, torna-se possível que ele sinta toda as questões fáticas e probatória daquela demanda.

Dessa forma, resta questionar se de fato a oralidade está sendo utilizada na litigância brasileira de forma adequada, e se pode ser considerada como um meio que viabiliza o combate à morosidade.

\section{Críticas à Utilização da Oralidade na Litigância Civil Brasileira}

Por se tratar de um instituto de extrema importância ao ordenamento jurídico brasileiro, é justo que se faça uma análise crítica à sua utilização atualmente.

O primeiro ponto a ser analisado, diz respeito ao uso do princípio da oralidade no processo civil, que não vem sendo feito da forma mais adequada e efetiva.

\subsection{Uso inadequado}

Conforme já mencionado no presente artigo, atualmente no Brasil o uso da oralidade se dá de forma mitigada, visto que no processo brasileiro é utilizado primordialmente a modalidade escrita de comunicação e realização dos atos processuais. No procedimento comum, a oralidade é evidente apenas na fases que contém audiências, seja ela conciliatória, ou em audiência de instrução e julgamento, onde o juiz ouvirá as partes, o perito se for o caso e as testemunhas, além de ouvir os debates orais finais - que poderão ser feitos em forma escrita, através dos memoriais escritos. Nesses os casos, é necessário reduzir a termo a descrição da audiência. Já o procedimento adotado pelos Juizados Especiais pode ser considerado primordialmente oral, em razão dos seguintes fatos: a petição inicial pode ser oral ou de forma escrita reduzida a termo pelo setor de atermação; a audiência de conciliação e a de instrução e julgamento são unas e indivisíveis, onde a parte contrária apresentará defesa de forma oral ou escrita e a sentença poderá ser prolatada de forma oral.

A finalidade primordial da oralidade é, além de trazer celeridade e efetividade ao procedimento, contribuir para que o juiz entenda precisamente o litígio e tudo aquilo que o envolve, para promover uma tutela jurisdicional satisfativa. Conforme afirma Ruiz e Rossaneis: "[...] a oralidade vem para aproximar as partes do Juiz, aumentando as chances do julgador de entender com clareza a ocorrência e a intensidade dos fatos trazidos ao juízo. Consequentemente, a marcha processual tende a se acelerar e contribuir para a prestação jurisdicional rápida e eficaz” (Ruiz \& Rossaneis, 2013, p. 247).

Entretanto, o uso inadequado é recorrente uma vez que se oportuniza momentos facultativos do uso oral, já que muitas vezes aqueles envolvidos no processo prezam por utilizar-se da escrita. É o caso das alegações finais, por exemplo, que embora possa ser feita oralmente ao final da audiência de instrução e julgamento, é muito comum que seja feita de forma escrita, em razão do art. $364, \S 2^{\circ}$, do CPC/15 prever essa ressalva, in verbis: 
Art. 364 do CPC/15. Finda a instrução, o juiz dará a palavra ao advogado do autor e do réu, bem como ao membro do Ministério Público, se for o caso de sua intervenção, sucessivamente, pelo prazo de 20 (vinte) minutos para cada um, prorrogável por 10 (dez) minutos, a critério do juiz. $\$ 1^{\circ}$ Havendo litisconsorte ou terceiro interveniente, o prazo, que formará com o da prorrogação um só todo, dividir-se-á entre os do mesmo grupo, se não convencionarem de modo diverso. $\S 2^{\circ}$ Quando a causa apresentar questões complexas de fato ou de direito, o debate oral poderá ser substituído por razões finais escritas, que serão apresentadas pelo autor e pelo réu, bem como pelo Ministério Público, se for o caso de sua intervenção, em prazos sucessivos de 15 (quinze) dias, assegurada vista dos autos (Brasil, 2015).

Isso acaba por influenciar na celeridade do procedimento, e na efetividade, já que as alegações finais orais trazem maior proximidades das partes com o juiz, além do fato de que são feitas naquele momento, não dando ao juiz a obrigação de lê-las em momento posterior. Dessa forma, é necessário a transição de uma mera faculdade, como uma obrigação perante às partes.

Ademais, conforme muito bem expõe Ruiz e Rossaneis (2013, p. 259), o uso realmente adequado da oralidade pressupõe uma preparação dos profissionais do Direito que poderão utilizá-la, como os advogados, partes, membros do Ministério Pública e o próprio juiz, para que estes tenham capacidade técnica mínima para produzir atos orais. Isso porque, de nada serve a imposição da oralidade na fase de alegações finais, por exemplo, se aqueles que forem fazer essas alegações não sejam capacitados para argumentar e expor fatos oralmente. Além disso, pressupõe também, para alcançar a oralidade efetiva nos atos processuais, que os operadores ali envolvidos conheçam o processo.

Conforme aponta Ruiz e Rossaneis (2013, p. 248), quanto ao uso nas audiência, em primeiro lugar, cabe salientar que nas audiências de conciliação, o que é muito recorrente são questionamentos feitos pelo juiz para saber se as partes desejam ou não um acordo, sem de fato proporcionar um momento confortável ou ao mesmo viável de conversa entre as partes. Isso, de fato, prejudica a aplicação da oralidade. Isso traz como consequência os seguintes pontos:

Ao agir desta forma, o Juiz compromete a rápida solução do litígio, que se trata de um dever que lhe é imposto por força de lei, no entanto, as consequências de tais atitudes vão além, ao não proceder a aplicação em conformidade com a legislação, fazendo observar a oralidade como mecanismo de agilidade, está, não somente negando seus deveres, como também a própria jurisdição, estando na contramão da tendência moderna da legislação processual (Ruiz \& Rossaneis, 2013, p. 248).

Ademais, outro ponto que cabe salientar é o fato de que, embora a lei preveja que "encerrado o debate ou oferecidas as razões finais, o juiz proferirá sentença em audiência ou no prazo de 30 (trinta) dias" (Brasil, 2015), essa faculdade acaba se tornando abertura para a escolha rotineira do juiz pela sentença escrita. Isso influencia em toda a proximidade que ele obteve com o litígio ao longo da audiência de instrução e julgamento, já que 30 dias depois "o papel e a escrita não tem a capacidade de reproduzir fielmente, nos mesmos moldes e intensidade, aquilo que as emoções foram capazes de captar naquele contato direito, o que pode acarretar em julgamento inadequado da lide” (Ruiz \& Rossaneis, 2013, p. 250).

Dessa forma, conclui-se que, embora prevista na legislação que rege a litigância civil brasileira, a oralidade não vêm sendo aplicada da melhor forma na prática. Em especial nos momentos em que é facultativo o uso da mesma, é necessário que se considera os benefícios ao processo que a sua utilização poderá causar, como uma maior celeridade na entrega da tutela jurisdicional efetiva. É indispensável, portanto, que os profissionais do Direito adquiram consciência desse benefício, além de capacidade técnica para exercer a oralidade. 


\subsection{Distanciamento da finalidade da jurisdição}

Conforme já mencionado, o uso inadequado da oralidade pode refletir em diversos malefícios às partes. Um deles, sem sombra de dúvidas, é a morosidade no recebimento na tutela, além dos riscos da mesma não ser justa ou efetiva ao caso concreto.

Dessa forma, conforme afirma Ruiz e Rossaineis, "o mau uso da oralidade desvia de seu curso natural o próprio processo e acarreta, portanto, em falha no funcionamento de toda a atividade jurisdicional" (Ruiz \& Rossaneis, 2013, p. 252). Isso quer dizer que o uso inadequado poderá causar um afastamento do cidadão ao seu direito de acesso à justiça, definido pela CRFB/88, e da tutela jurisdicional, não caracterizando assim em uma jurisdição concreta.

A regra é que o Estado tem o poder-dever de promover a jurisdição, conforme afirma Lima:

o conflito de interesses surge quando mais de um indivíduo busca desfrutar o mesmo bem. A lide tem origem quando $o$ conflito de interesses resultante do concurso pelo mesmo bem não se resolve de forma natural entre as partes. Então, ambos resistirão ao que lhes são exigidos um pelo outro, de modo que caberá ao Estado, detentor do poderdever de jurisdição, dirimir tais conflitos e declarar direitos (Lima, 2008, s.p.).

Dessa forma, a partir do momento que o Estado não toma medidas efetivas para o uso adequado da oralidade, ele não promove a jurisdição plena, que não abrange toda a efetividade a ela inerente, da maneira como deveria ser.

Conforme muito bem explica Ruiz e Rossaineis (2013, p. 255), não basta apenas promover uma solução ao caso concreto, mas é necessário também colocar fim ao conflito fático entre as partes, além de ser indispensável que o direito seja dado à elas da forma correta. Inclusive, essa postura pode até mesmo ser considerada como inibitória, já que terceiros poderão ficar mais receosos em violar a lei já que a sua correta aplicação traz estabilidade à instituição, além de que passam a ter certeza que a jurisdição facilmente incidirá sob a situação e promoverá a solução mais justa e adequada. Inclusive, a oralidade:

[...] como vem sendo utilizada faz com que o processo desvie-se de suas funções, prejudicando o exercício adequado da jurisdição, que não consegue atingir seus fins. O que se deve ter em mente quando depara-se com esta situação é que a inefetividade da jurisdição não fica restrita a inefetividade de um poder estatal, mas sim compromete a efetividade dos direitos, o que certamente não pode ser admitido (Ruiz \& Rossaneis, 2013, p. 255).

Por último, cabe ressaltar que formalidades excessivas, como a obrigatoriedade no uso da escrita em determinados atos, podem também inviabilizar o exercício da jurisdição e a prestação satisfativa. Inclusive, o mundo vêm passando por um período de avanço tecnológico gigantesco e isso poderá ser utilizado para quebrar paradigmas antigos, como a necessidade de adoção da escrita quando há outros meios para se alcançar a mesma finalidade. Dessa forma, é necessário olhar para essas formalidades criticamente e nunca deixar de considerar a evolução da sociedade e suas necessidades.

\subsection{Conflito de interesses e corrupção judicial lato sensu}

A corrupção judicial lato sensu está inteiramente ligada á eficácia da norma jurídica, razão pela qual merece ser indagado, no presente artigo, como o distanciamento dessa eficácia poderá caracterizar-como como uma espécie de corrupção.

A corrupção judicial lato sensu trata-se de uma forma de corrupção que não é abrangido por um tipo penal ou administrativo específico, ou seja, refere-se à atividades potencialmente corruptas mas que não são abarcadas pelas sanções dadas pela legislação. Dessa forma, têm-se a utilização da palavra no sentido de ruptura e decomposição, onde infere-se uma corrupção legal.

A ineficácia das normas reguladoras do princípio da oralidade é, sem sombra de dúvidas, uma hipótese de corrução lato sensu. Tal afirmativa se justifica na medida em que a ineficácia de qualquer norma ou instituto previamente estabelecido 
pelo Estado, através dos poderes Judiciário ou Legislativo, pressupõe um ruptura quanto as metas e finalidades da norma. É, portanto, uma espécie de distanciamento da finalidade da jurisdição.

Conforme já exposto no presente artigo, esse distanciamento caracterizará, certamente, em malefícios ao processo, uma vez que a oralidade se desenvolve para prover benefícios, como a celeridade processual e a prolação de decisões mais pertinentes e adequadas, conferindo portanto maior eficácia à tutela jurisdicional. Um dos malefícios proporcionados pela corrupção judicial lato sensu seria, justamente, o emprego de etapas processuais mais morosas por parte dos sujeitos que participam daquelas relações processuais, como por exemplo a utilização das alegações finais de forma escrita, mesmo que a legislação já preveja, de forma expressa, a faculdade de serem feitas de forma oral.

Dessa forma, é necessário que todas os sujeitos do processo manejem meios que promovam eficácia à tutela jurisdicional, através do uso adequado da oralidade, para enfim se distanciarem cada vez mais da prática de corrupção judicial lato sensu.

Um meio adequado para fins de viabilização da efetividade jurisdicional, afastando-se assim de eventual corrupção judicial lato sensu, seria justamente a adoção mais recorrente de despachos orais entre a figura do juiz e os advogados das partes, de forma a tornar o trâmite processual mais célere, conforme já foi discutido na presente pesquisa.

Isso porque, como é notório, é possível que haja no processo conflitos de interesses entre a relação do juiz com os advogados das partes, como por exemplo a demora para que o juiz profira despacho após os autos irem conclusos para o juiz, ficando o processo literalmente parado por tempo demasiadamente longo. Há um nítido conflito de interesses, uma vez que os advogados das partes querem que a tutela jurisdicional seja promovida para seu cliente de forma mais célere possível.

Nesse caso, e em diversos outros em que há conflito de interesses entre estes sujeitos processuais, a possibilidade de despachos orais poderia ser manifestamente positivo à celeridade processual, já que através disso é possível um certo tráfego de influências entre ambos. Esse tráfego vem da possibilidade do juiz "sentir" a demanda, que, como já foi abordado anteriormente, promove um melhor e consequentemente mais adequado entendimento acerca das questões fáticas pelas quais se funda o processo, já que muitas vezes, na forma escrita, é mais difícil explicar de forma clara e precisa o que realmente se quer manifestar. Isso acaba facilitando a atividade jurisdicional e a atividade do advogado, além de promover um acesso à justiça no sentido de efetividade do termo para as partes.

Dessa forma, os juízes devem estar constantemente preparados - e se façam disponível - para receber advogados em seus gabinetes a fim de que seja realizado despachos orais, uma vez que os benefícios advindos dessa conduta é notório e substancial. Aos advogados também cabe a feitura de uma análise cautelosa - ou seja, é necessário uma posição mais ativa do que inerte - no que tange a até que momento a demora processual é normal e não maléfica, para que possa utilizar-se da possibilidade de despacho orais em prol do combate á morosidade processual.

\section{Governança Judicial como Solução e Efetividade da Oralidade}

Em razão da ineficácia e da morosidade inerente ao Poder Judiciário brasileiro e sua atuação nos dias atuações, fazese premente a constante análise crítica desses problemas, de forma a concluir por soluções para mitigar seus efeitos ou mesmo dar fim à essa triste realidade, uma vez que esta distancia-se da tutela jurisdicional adequada que deve ser conferida aos litigantes, para assegurar seu direito constitucional de acesso à jurisdição.

Uma dessas soluções cabíveis seria a implementação efetiva do princípio da oralidade no sistema jurídico brasileiro através de diversas formas, como as já mencionadas no presente artigo. Uma das formas que neste tópico se pretende explicar e defender é a aplicação da governança judicial nas relações jurídicas processuais. É notória a importância da aplicação da governança judicial como forma de dar efetividade a oralidade. 
O instituto se refere a uma espécie de gestão judiciária, que visa apresentar soluções de melhoria e efetividade ao desempenho do sistema judiciário, onde a transparência e a participação são elementos essenciais aos feitos em trâmites, não apenas situações excepcionais para a prolação das decisões. Tratam-se, portanto, de estudos e análises de desempenho, no que tange "independência judicial, accountability, recursos estratégicos do Poder Judiciário, acessibilidade à Justiça e estrutura do Poder Judiciário" (Silveira, Clementino \& Almeida, 2020, p. 321).

O ordenamento jurídico brasileiro já conta com a oralidade, sendo um recurso estratégico interessante no que tange a efetividade. Entretanto, a governança judicial deverá incidir na aplicação desse princípio nos processos judiciais, de forma geral. Justifica-se tal afirmativa porque o instituto aqui defendido pressupõe um liame entre sociedade e Poder Público, que devem unir esforços para resolver dilemas comuns. É obvio que para se alcançar a governança deve existir uma integração harmônica entre Estado, instituições e cidadãos ${ }^{3}$.

Nesse contexto e para o Direito, a governança, além de criar normas para efetivar tal participação, embora, às vezes, sem estrita formalização institucional, promove meios de efetivar as normas já instituídas. Por esse motivo, torna-se indispensável a utilização da governança na aplicação das fases orais do processo brasileiro, uma vez que a oralidade pressupõe, conforme já defendido no presente artigo, uma maior participação dos sujeitos processuais.

Portanto, a atividade instrutória deveria ser mais participativa através de uma oralidade persistente. Uma solução plausível seria a conscientização, através de uma política de majoração da porcentagem dos honorários de sucumbência em razão da celeridade procedimental, previamente disposta na legislação, dos advogados das partes litigantes para que, sempre que a lei determinar uma faculdade da utilização da modalidade oral em determinada fase, a atuação seja feita dessa forma, o que implicaria em uma tutela jurisdicional mais célere para seus clientes. A mera imposição da escolha pela modalidade oral pode não ser o melhor caminho, já que poderá levar aos advogados a atuarem de forma indevida, conforme a oralidade. Portanto, o estabelecimento de benefícios mediante o uso da modalidade, mesmo quando facultativa, pode alcançar exposições e debates orais completos e bem fundamentados, o que consequentemente levará a uma instrução elaborada e uma eventual decisão mais eficaz.

Quanto aos juízes e demais componentes do Poder Judiciário, é razoável pensar que o CNJ, como órgão que administra todo o Poder Judiciário brasileiro, poderia estabelecer uma governança judicial impondo resoluções que criam medidas de conscientização dos "agentes da justiça", para que eles venham a escolher a oralidade quando lhes for facultado, ao entender que é a forma mais efetiva de tutela jurisdicional adequada, além da instituição de cursos preparatórios de oratória, de mediação e conciliação, dentre outros, para que os profissionais sejam mais bem preparados para utilização da oralidade e da imposição dos subprincípios da oralidade. Conforme afirma Ragone e Vélez, "la oralidad que ahora se logra imponer constituye la evidente opción del legislador por las ventajas y posibilidades que viene a aportar la mayor flexibilidad y espontaneidad en el diálogo y procedimiento probatorio"4 (Ragone \& Vélez, 2009, p. 394).

A transparência, de fato, deverá ser adotada em todo o procedimento, tanto na fase preliminar, instrutória ou decisória, por meio do respeito pelo Poder Judiciário, do contato direto entre os juízes e partes, principalmente em casos envolvendo pessoas hipossuficientes, uma vez que:

[...] o mero fato de lhes serem franqueadas a possibilidade de estar na sala de audiência na presença de um juiz é um fator que resgata algum senso de dignidade e cidadania. É certo que isso é um fator cultural que em boa medida se perde em grandes centros urbanos. Mas em pequenas localidades do interior a imagem institucional do Poder Judiciário se confunde sobremaneira aos olhos da população com a própria pessoa do juiz. Neste cenário, a

\footnotetext{
${ }^{3}$ Para aprofundamentos, ver: Estanislau e Gomes, 2019, p. 01-16.

${ }^{4}$ Tradução livre: "a oralidade que se impõe constitui a opção óbvia do legislador pelas vantagens e possibilidades que vem proporcionar maior agilidade e espontaneidade no diálogo e no procedimento probatório" (Ragone \& Vélez, 2009, p. 394).
} 
audiência representa ao jurisdicionado uma reafirmação de transparência no julgamento de sua demanda (Iura, 2012, p. 110) $)^{5}$.

Conclui-se, portanto, que a governança não é algo somente para ser apreciado, mas sim para ser aplicado e efetivado. É, sem sombra de dúvida, um caminho ao acesso à justiça e não mais justo que aplicá-la para alcançar efetividade em princípios já consagrados pelo processo civil, como o da oralidade.

\section{Considerações Finais}

Com o desenvolvimento do presente artigo, percebeu-se a notória importância da aplicação da oralidade no processo civil, já que ela auxilia na construção de um amplo acesso à jurisdição, de forma efetiva, adequada e sustentável. Entretanto, também não há dúvidas que o tema merece ascensão, seja em debates e estudos, seja na prática forense, no que tange à sua aplicação.

A aplicação de uma governança judicial, como uma espécie de gestão judiciária, na execução do princípio da oralidade é uma grande solução para que ele tenha eficácia suficiente para alcançar suas finalidades.

Dessa forma, nada mais coerente afirmar que, através da governança judicial, é possível uma verdadeira participação e transparência na litigância, participação esta que advém em conjunto e cooperação das partes e seus advogados, membros do Ministério Público, defensores públicos, magistrados e os demais sujeitos processuais indispensáveis para o alcance da justiça. Por esse motivo, se torna indispensável a instituição de mecanismos para efetivar normas que preveem a oralidade em seu texto, como a aplicação de uma política de majoração de percentual de honorários conforme foi exposto no presente artigo, além da preparação profissional e instituição de política de conscientização, partindo do CNJ, de todos os agentes da justiça, para que assim possam, e escolham, aplicar a oralidade em todos os momentos processuais possíveis.

É indispensável, portanto, para o amplo acesso à jurisdição uma cooperação real e efetiva entre todos os sujeitos do processo, no que tange aos atos processuais orais, de forma a entender a sua real importância e seus benefícios, a fim de que se faça uma escolha consciente na sua adoção.

Sugere-se, para futuros trabalhos, a análise das repercussões da jurisdição sustentável no Direito processual brasileiro.

\section{Agradecimentos}

Trabalho financiado pelo Edital no 03/2020 de Incentivo à Pesquisa da Escola Superior Dom Helder Câmara, resultante dos Grupos de Pesquisas (CNPQ): Responsabilidade Civil e Processo Ambiental (RECIPRO), NEGESP, Metamorfose Jurídica e CEDIS (FCT-PT).

Este artigo é uma versão escrita da palestra ministrada no Curso de Especialização: estratégias de litigância oral interdisciplinares, fornecido pelo Colegio de Abogados de Arequipa (Peru) e outras instituições intercontinentais, em 24/04/2021, às 11 horas peruanas.

\section{Referências}

Baptista, B. G. L. (2008). A Oralidade Processual e a Construção da Verdade Jurídica. Revista da Seção Judiciária do Rio de Janeiro, 23 , 131-160. Brasil. Constituição (1988). Constituição da República Federativa do Brasil. Diário Oficial, Brasília, 05 out. 1988.

Brasil (1973). Lei no 5.869, de 11 de janeiro de 1973. Instituo o Código de Processo Civil. Diário Oficial da União, 17 jan. 2006. http://www.planalto.gov.br/ccivil_03/leis/L5869impressao.htm.

${ }^{5}$ Para estudar outros aspectos da transparência judicial, especialmente no Processo Judicial eletrônico, ver: Estanislau e Gomes, 2019 , 3-4 e 10-13. 
Brasil (2015). Lei 13.105 de 16 de março de 2015. Código de Processo Civil. Diário Oficial da União, 17 mar. de 2015. http://www.planalto.gov.br/ccivil_03/_ato2015-2018/2015/lei/113105.htm.

Bueno, D. M. (2018). A irrecorribilidade das decisões interlocutórias na ótica do novo CPC. https://www.correioforense.com.br/dir-processual-civil/airrecorribilidade-das-decisoes-interlocutorias-na-otica-do-novo-cpc/\#: :text=a\%20oralidade $\% 20$ privilegia $\% 20 \mathrm{a} \% 20 \mathrm{concentra} \% \mathrm{c} 3 \% \mathrm{a} 7 \% \mathrm{c} 3 \% \mathrm{a} 3 \mathrm{o}, \% \mathrm{c} 3 \% \mathrm{a} 0 \%$ 20dura\% c3\%a7\%c3\%a3o\%20razo\%c3\%a1vel\%20do\%20processo.

Chiovenda, G. (1965). Instituições de direito processual civil. Saraiva. (2a ed.).

Estanislau, F. N. \& Gomes, M. F. (2019). O processo judicial eletrônico, o direito ao desenvolvimento e a boa governança: o caminho para a sustentabilidade. Revista da Faculdade de Direito da UFG, 43(9), 01-16. https://doi.org/10.5216/rfd.v43.44591

Gomes, M. F \& Ferreira, L. J. (2017). A dimensão jurídico-política da sustentabilidade e o direito fundamental razoável duração do procedimento. Revista do Direito, 2(52), 93-111. https://www.researchgate.net/publication/321074014_A_dimensao_juridico-politica_da_sustentabilidade_e_o_di reito_fundamental_a_razoavel_duracao_do_procedimento.

Gouvêa, R. B. O. (2017). A aplicação do princípio da oralidade no Processo Civil Brasileiro e Alemão. In: O labirinto da codificação do Direito Internacional Privado. Anais do II Congresso de Processo Civil Internacional. p. 77-92.

Iura, A. M. (2012). Oralidade e escrita no processo civil. Faculdade de Direito da Universidade de São Paulo. https://www.teses.usp.br/teses/disponiveis/2/2137/tde-06062013-133608/publico/Mestrado_Alexandre_Miura_Iura_versao_integral.pdf.

Lima, W. (2008). Uma nova abordagem da jurisdição no Processo Civil contemporâneo. https://ambitojuridico.com.br/cadernos/direito-processual-civil/umanova-abordagem-da-jurisdicao-no-processo-civil-contemporaneo/.

Lopes Jr., A. (2004). Introdução crítica ao processo penal: fundamentos da instrumentalidade garantista. Lumen Juris.

Maranguape, A. L. V. \& Maranguape, F. E. V. \& Vasconcelos, D. F. (2020). A morosidade do âmbito judiciário. https://ambitojuridico.com.br/cadernos/direi to-processual-civil/a-morosidade-no-ambito-judiciario.

Mezzaroba, O., \& Monteiro, C. S. (2009). Manual de metodologia da pesquisa no direito. Saraiva. (5a ed.)

Peyrano, J. W. (2008). La prueba entre la oralidad e la escritura. Coloquio de la Asociación Internacional de Derecho Procesal, 1, 149-173. https://dialnet.unirioja.es/servlet/articulo?codigo=7126515.

Ragone, A. P. \& Vélez, D. P. (2009). Oralidad y prueba: comparación y análisis crítico de las experiencias reformadoras del proceso civil en Alemania y España. Revista de Derecho de la Pontificia Universidad Católica de Valparaíso, (32), 363-406. https://scielo.conicyt.cl/scielo .php?script=sci_arttext\&pid=S0718-68512009000100011.

Ruiz, I. A. \& Rossaneis, A. C. (2013). Estudo crítico do princípio da oralidade no processo civil: releitura da utilização como instrumento de efetivação dos direitos de personalidade. In: Iocohama, C. H. \& Saldanha; J. M. L. \& Leite, F. (Coords.). Processo e jurisdição I. CONPEDI.

Santos, M H. C. (1997). Governabilidade, governança e democracia: criação da capacidade governativa e relações executivo-legislativo no Brasil pósconstituinte. Dados - Revista de Ciências Sociais, 40 (3), p. 335-376. http://www.scielo.br/scielo.php?script=sci_arttext\&pid=S0011-52581997000300003.

Silveira, R. M. C \& Clementino, M. L. M \& Almeida, L. S. B. (2020). Governança judicial: uma análise dos desafios para a prestação do serviço jurisdicional. Revista do Serviço Público, 71 (3), 315-344. https://revista.enap.gov.br/index.php/RSP/article/view/4569/2853.

Souza Netto, J. L. (2016). A confluência dos modelos dispositivos e inquisitivo do processo civil operada pelo princípio da cooperação. In: Nascimento, G. A. F \& Ramos, P. R. B. \& Martins, A. C. M (coords). Constituição e Democracia II, 1, 402-419. https://www.conpedi.org.br/publicac oes/y0ii48h0/509my5cz/jQArPjlHT61BmF15.pdf.

Souza Netto, J. L. S \& Guilherme, G. C.; Garcel, A.; \& Cochran, A. B. (2020). O processo civil constitucional e os efeitos do princípio da cooperação na resolução de conflitos. Revista Jurídica Unicuritiba, 2(59), 577-600. http://revista.unicuritiba.edu.br/index.php/RevJur/article/view/4411/371372652.

Talamini, E. (2016). Saneamento e organização do processo no CPC/15. https://www.migalhas.com.br/depeso/235256/saneamento-e-organizacao-doprocesso-no-cpc-15.

Theodoro Junior, H. (2005). Celeridade e efetividade da prestação jurisdicional: insuficiência da reforma das leis processuais. Revista Síntese de Direito Civil e Processual Civil, 6 (36). http://www.abdpc.org.br/artigos/artigo51.htm.

Theodoro Junior, H. (2015). Curso de Direito Processual Civil. Forense. (56a ed.).

Wach, A. (1879). Vortrage über die Reichs-Civilprocessordnung. Adolf Marcus. 